\title{
Possibilities, Problems, and Perspectives of Data Collection by Mobile Apps in Longitudinal Epidemiological Studies: Scoping Review
}

\author{
Florian Fischer ${ }^{1,2,3}$, PhD; Sina Kleen ${ }^{3}$, MSc \\ ${ }^{1}$ Institut of Public Health, Charité - Universitätsmedizin Berlin, Berlin, Germany \\ ${ }^{2}$ Institute of Gerontological Health Services and Nursing Research, Ravensburg-Weingarten University of Applied Sciences, Weingarten, Germany \\ ${ }^{3}$ Department of Population Medicine and Health Services Research, School of Public Health, Bielefeld University, Bielefeld, Germany
}

\section{Corresponding Author:}

Florian Fischer, $\mathrm{PhD}$

Institut of Public Health

Charité - Universitätsmedizin Berlin

Charitéplatz 1

Berlin, 10117

Germany

Phone: 497515019441

Email: florian.fischer1@ charite.de

\section{Abstract}

Background: The broad availability of smartphones and the number of health apps in app stores have risen in recent years. Health apps have benefits for individuals (eg, the ability to monitor one's health) as well as for researchers (eg, the ability to collect data in population-based, clinical, and observational studies). Although the number of health apps on the global app market is huge and the associated potential seems to be great, app-based questionnaires for collecting patient-related data have not played an important role in epidemiological studies so far.

Objective: This study aims to provide an overview of studies that have collected patient data using an app-based approach, with a particular focus on longitudinal studies. This literature review describes the current extent to which smartphones have been used for collecting (patient) data for research purposes, and the potential benefits and challenges associated with this approach.

Methods: We conducted a scoping review of studies that used data collection via apps. PubMed was used to identify studies describing the use of smartphone app questionnaires for collecting data over time. Overall, 17 articles were included in the summary.

Results: Based on the results of this scoping review, there are only a few studies that integrate smartphone apps into data-collection approaches. Studies dealing with the collection of health-related data via smartphone apps have mainly been developed with regard to psychosomatic, neurodegenerative, respiratory, and cardiovascular diseases, as well as malign neoplasm. Among the identified studies, the duration of data collection ranged from 4 weeks to 12 months, and the participants' mean ages ranged from 7 to 69 years. Potential can be seen for real-time information transfer, fast data synchronization (which saves time and increases effectivity), and the possibility of tracking responses longitudinally. Furthermore, smartphone-based data-collection techniques might prevent biases, such as reminder bias or mistakes occurring during manual data transfers. In chronic diseases, real-time communication with physicians and early detection of symptoms enables rapid modifications in disease management.

Conclusions: The results indicate that using mobile technologies can help to overcome challenges linked with data collection in epidemiological research. However, further feasibility studies need to be conducted in the near future to test the applicability and acceptance of these mobile apps for epidemiological research in various subpopulations.

(J Med Internet Res 2021;23(1):e17691) doi: 10.2196/17691

\section{KEYWORDS}

apps; questionnaire; survey; epidemiology; healthcare 


\section{Introduction}

Worldwide, there were 2.39 billion smartphone users in 2017, and this number is predicted to exceed three billion by 2021 [1]. Undoubtedly, smartphones have become part of everyday life for many people around the world. Alongside the increase in smartphone use, the market for smartphone apps has risen massively in recent years [2]. In health care, it is anticipated that apps have the potential to decrease both spatial and administrative barriers [2]. However, removing barriers is only one potential outcome resulting from the use of these applications. The market for mHealth apps is growing rapidly. In 2015 alone, there were more than 100,000 new health apps published in relevant app stores, with approximately three billion downloads of apps related to health, fitness, and medicine [2]. In comparison to 2013, the number of downloaded apps has almost doubled [2]. Consumers use apps to track steps, heart rate, sleep patterns, and so forth. Smartphones also function as new tools for measuring the health of individuals. Moreover, smartphone apps may deliver data at the population level. For that reason, smartphones are expected to be beneficial to health care research and epidemiological studies. Over the last two decades, surveys have ceased to exclusively use traditional methods of data collection, such as paper or telephone-based questionnaires; questionnaires have instead been developed using electronic systems, such as internet-based surveys and personal digital assistants. Although there has been a huge rise in the use of smartphones, issues regarding the benefits and potential uses of app-based questionnaires still need to be addressed [3]. Various studies have developed smartphone apps for educational or communication purposes for medical school students and clinicians [4]. However, only a few questionnaires on smartphone apps have been used in clinical settings, such as in sleep disorder tracking and for the administration of psychiatric questionnaires [5-7]. Beyond epidemiology, public health, and health services research, there are approaches in the field of cognitive science that have also detected the potential for data collection via smartphone apps [8].

Although data collection using smartphone apps has not yet been comprehensively studied and is not very frequently used, the availability of and access to smartphones among the world's population raises the potential for large-scale surveys in (longitudinal) population-based studies. This scoping review focuses on studies investigating the acceptability, feasibility, and performance of mobile apps for data collection in longitudinal studies, irrespective of the studies' purposes (eg, measuring vital parameters, providing questionnaires) or the types of apps in question (eg, apps that are medical products prescribed by physicians or those that are lifestyle products selected by users). To guide the scoping review, we focused on the following 4 overarching research questions: 1) which types of studies (feasibility/pilot vs full-scale) have been conducted to date, 2) over what period of time has data been collected within these studies, 3) which specific target groups (eg, children, elderly, migrants) have been included in the studies, and 4) what potential benefits and challenges to app-based data collection are described in the studies?

\section{Methods}

We conducted a scoping review using PubMed. In the first step, we employed a broad search strategy to include all articles dealing with apps, smartphone devices, or mHealth in the context of data-collection activities. Hence, the following search algorithm was used:

$\begin{array}{lrr}\text { (app[Title/Abstract] } & \text { OR apps[Title/Abstract] } & \text { OR } \\ \text { smartphone*[Title/Abstract] } & \text { OR } \\ \text { mHealth[Title/Abstract] } & \text { OR } & \text { "mobile } \\ \text { health"[Title/Abstract] } & \text { OR } & \text { mobile } \\ \text { phone*[Title/Abstract]) AND(cohort*[Title/Abstract] } \\ \text { OR survey*[Title/Abstract] r } & \text { OR } \\ \text { questionnaire*[Title/Abstract]) } & \end{array}$

All articles published up to December 31, 2017 were considered by two independent reviewers. This led to 1922 matches after incorporating the predefined filters for studies conducted among humans and those written in the requisite publication language(s) (English or German). The following main exclusion criteria were defined a priori:

- $\quad$ SMS-based approaches (including SMS reminders and supportive text messages in interventional studies)

- Web-based approaches/questionnaires, which can also be conducted on smartphones

- Nomophobia (fear of being out of cellular phone contact)

- Distraction by smartphones while driving

- "App" as an abbreviation for unrelated issues (eg, amyloid precursor protein)

- Screen media time usage among children or adolescents

- Mobile phone access and usage in various populations

- Validation of paper-based compared with software/app-based questionnaires

- Articles dealing with Electronic Health Records

- mHealth interventions using apps only for treatment or educational purposes (eg, limited to disease treatments)

After screening all article titles and abstracts against the criteria listed above, 1808 articles were excluded. This led to 114 articles for which a review of the full text was performed. Due to the large number of articles still remaining, further exclusion criteria were defined and the particular reason for exclusion was documented. Using this procedure, 97 further articles were excluded for the following reasons:

- Cross-sectional study design [9-15]

- Qualitative study design [16]

- Study protocol [17]

- App without purpose of data collection [18-26]

- App only for self-monitoring or willingness to self-monitor disease or certain lifestyle measures (no data storage for researcher) [27-48]

- Mobile-type programs/programmed phones, personal monitors, or ecological momentary assessment protocols displaying on mobile phone screens (without the involvement of an app) [49-52]

- Advanced data-collection systems without the need for data entry by the patient/interviewee (eg, using Global 
Positioning System location and phone usage data automatically) [53-55]

- App as assistive working tool for researchers or medical staff (no data entry from interviewees/patients) [56-73]

- Study duration less than one month or one-time data entry [47,74-100]

- No possibilities, problems, or perspectives mentioned in the study [101]

- Reviews dealing with smartphone apps, mobile phone surveys, and new data-collection methods in general [102-105]

Thus, studies included in the review met the following criteria:

- Data collection with a smartphone app, including apps used for disease screening

- Apps either prescribed by a physician or selected by the user

- More than self-management functions

- App available on smartphone

Figure 1. Flowchart of the scoping review.

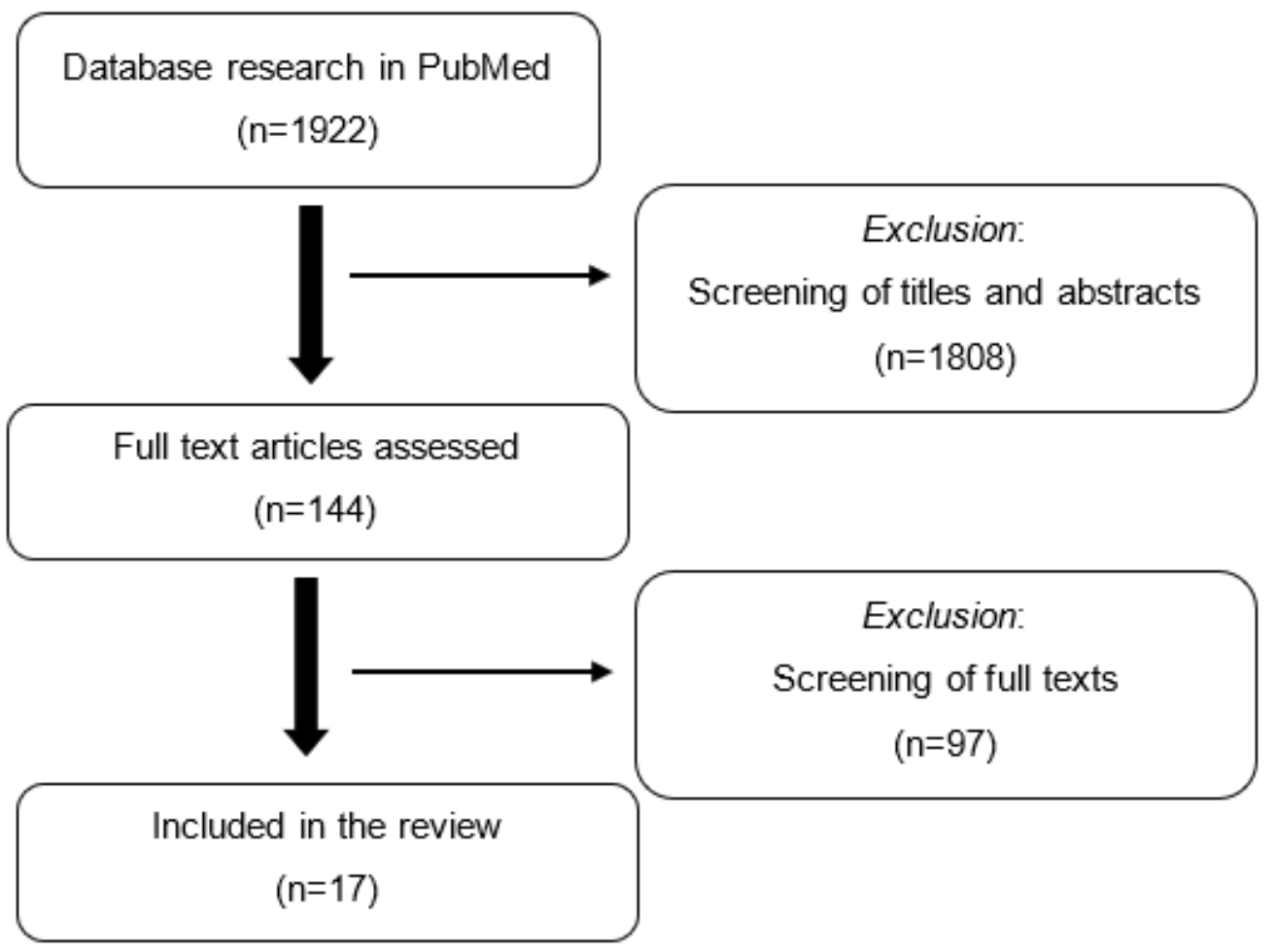

\section{Results}

Overview: Studies Collecting Patient Health Data Over

\section{Time}

A total of 17 studies were included in the synthesis of the scoping review (Table 1). These studies were conducted for the following reasons:

- To track real-time changes in symptom(s) (severity) or other disease-related patterns (for creating modified/redefined treatment plans) [106-115]

- To determine users' compliance and engagement with technology adoption, patient data collection, and provider communication with smartphone app $[107,111,112,114,115]$
- Data entry completed by the interviewees/patients (or close relatives)

- Repeated data entry on a longitudinal basis (more than one month)

- Possibilities, problems, and perspectives of data-collection apps described

- Feasibility studies with attitudes toward

sharing

health information (with researchers or physicians) within smartphone apps or smartphone devices

The final summary consisted of 17 studies, which were summarized using content analysis (Figure 1). There were 3 guiding questions for the content analysis: (1) in which settings have apps for data collection been used so far, (2) what challenges and requirements exist regarding the implementation of apps, and (3) what potential does data collection with smartphone devices have? These aspects are synthesized in the Results based on those aspects described in the primary articles.
Exclusion:

$(n=1808)$
- $\quad$ To test an app for aftercare assessment [116-118]

- To screen for certain (disease or patient-related) outcomes [119]

- To develop an app-based participatory surveillance system for collecting syndromic data [120]

- To provide a practical guide to developing and implementing a longitudinal study with an app [121]

Of these 17 studies, 7 were feasibility or pilot studies. The country with the largest number of studies was the US (7/17); 2 studies based in Sweden and 2 more were based in the Netherlands. All (feasibility/pilot and full-scale) studies on data collection over a longer period of time using smartphone devices used a medical or health-related indication, with a wide range of indication areas. The two main indication areas were 
psychosomatic disorders (eg, depression, mood, post-traumatic stress disorder) and neurodegenerative diseases (eg, Parkinson Disease). The other studies focused on indication areas such as respiratory diseases (eg, asthma), cardiovascular diseases (eg, acute stroke, atrial fibrillation), malignant neoplasms (eg, prostate cancer), sleeping disorders (eg, insomnia, sleep apnea), infectious diseases (eg, acute febrile illness and gastroenteritis), weight loss in obese people, gestational diabetes mellitus, abdominal surgery, chronic pain, and drinking behavior in adolescents. Target groups were related to pregnancy (breastfeeding [108], depression [109], and gestational diabetes mellitus [122]) or focused on children [120] and young people [119].

Table 1. Overview of studies included in the scoping review.

\begin{tabular}{|c|c|c|c|c|c|c|c|}
\hline Reference & $\begin{array}{l}\text { Feasibility or } \\
\text { pilot study }\end{array}$ & Country & Indication area & Study design & $\begin{array}{l}\text { Duration of } \\
\text { data collection }\end{array}$ & $\begin{array}{l}\text { Participants at } \\
\text { baseline, } \mathrm{n}\end{array}$ & $\begin{array}{l}\text { Specific target } \\
\text { group }\end{array}$ \\
\hline Bot et al (2016) [106] & $\checkmark$ & US & Parkinson disease & Observational & 6 months & 8320 & $\mathrm{~N} / \mathrm{A}^{\mathrm{a}}$ \\
\hline Burke et al (2017) [121] & $\checkmark$ & US & Obesity & Observational & 12 months & 151 & N/A \\
\hline Chan et al (2017) [107] & $\mathrm{X}^{\mathrm{b}}$ & US & Asthma & Observational & 6 months & 7593 & N/A \\
\hline Cooray et al (2015) [116] & $\mathrm{X}$ & Sweden & Stroke & Cohort & 2 months & 48 & N/A \\
\hline Demirci and Bogen (2017) [108] & $\mathrm{X}$ & US & Breastfeeding & Observational & 8 weeks & 61 & Pregnancy \\
\hline Faherty et al (2017) [109] & $\mathrm{X}$ & US & Depression & Cohort & 8 weeks & 36 & Pregnancy \\
\hline Horsch et al (2017) [110] & $\mathrm{X}$ & Netherlands & Insomnia & $\mathrm{RCT}^{\mathrm{c}}$ & $\begin{array}{l}\text { 6-7 weeks } \\
\text { (with 3-month } \\
\text { follow-up) }\end{array}$ & 151 & N/A \\
\hline Isetta et al (2017) [111] & $\checkmark$ & Spain & $\begin{array}{l}\text { Obstructive sleep } \\
\text { apnea }\end{array}$ & Observational & 6 weeks & 60 & N/A \\
\hline Jamison et al (2017) [112] & $\checkmark$ & US & Chronic pain & Observational & $\begin{array}{l}3 \text { months } \\
\text { (with option } \\
\text { for } 6 \text { months) }\end{array}$ & 105 & N/A \\
\hline Labhart et al (2017) [119] & $\mathrm{X}$ & Switzerland & $\begin{array}{l}\text { Alcohol consump- } \\
\text { tion }\end{array}$ & Observational & 7 weeks & 176 & Young people \\
\hline Noe et al (2017) [113] & $\mathrm{X}$ & Wales & Mood tracking & Observational & 8 weeks & 76 & N/A \\
\hline Olson et al (2017) [120] & $\mathrm{X}$ & Guatemala & $\begin{array}{l}\text { Acute febrile ill- } \\
\text { ness and acute } \\
\text { gastroenteritis }\end{array}$ & Cohort & 9 months & 469 & Children \\
\hline Pavliscsak et al (2016) [117] & $\checkmark$ & England & $\begin{array}{l}\text { PTSD and/or TBI } \\
\text { in rehabilitation }\end{array}$ & $\mathrm{RCT}$ & 36 weeks & 95 & N/A \\
\hline Peleg et al (2017) [122] & $\checkmark$ & $\begin{array}{l}\text { Italy and } \\
\text { Spain }\end{array}$ & $\begin{array}{l}\text { Atrial fibrillation } \\
\text { and gestational } \\
\text { diabetes mellitus }\end{array}$ & Cohort & 9 months & 29 & Pregnancy \\
\hline Silva de Lima et al (2017) [114] & $\mathrm{X}$ & $\begin{array}{l}\text { Netherlands } \\
\text { and North } \\
\text { America }\end{array}$ & Parkinson disease & Observational & 6-13 weeks & 953 & N/A \\
\hline Sundberg et al (2017) [115] & $X$ & Sweden & Prostate cancer & Intervention & 11 weeks & 130 & N/A \\
\hline Symer et al (2017) [118] & $\checkmark$ & US & $\begin{array}{l}\text { Abdominal } \\
\text { surgery }\end{array}$ & Observational & 4 weeks & 31 & N/A \\
\hline
\end{tabular}

${ }^{\mathrm{a}} \mathrm{N} / \mathrm{A}$ : not applicable.

b Studies marked with an "X" are not feasibility or pilot studies.

${ }^{\mathrm{c}} \mathrm{RCT}$ : randomized controlled trial.

The sample sizes differed greatly, ranging from 29 to 8320 study participants at baseline. The participants' mean ages ranged from 7 years [120] (although children did not enter data unsupervised, and so parents were necessarily involved) to 69 years [115], although not every study provided information on the (mean) age of study participants. The majority of studies (10/17) had an observational design, with one using an ecological momentary assessment [121]. Of the observational studies, 4 were cohort studies, 2 were randomized controlled trials, and 1 was a nonrandomized controlled intervention trial. The duration of data collection varied between the studies from 4 weeks to 12 months. Further details are provided in Multimedia Appendix 1. 


\section{Potential of Using Smartphone Devices for Data Collection Over Time}

Within the reviewed articles, several potential benefits of using smartphone devices for data collection are described. Firstly, automatic push notifications offer the potential to provide daily, weekly, or monthly reminders or any kind of information [117]. This can be linked to multiple further functions, showing advantages for researchers as well as for users. For that reason, an app can be used as a data-collection tool or as a reminder for the elderly, has potential for self-interventions (eg, when users can track their symptoms), and can be used for real-time information transfer. Patients tracking their symptoms, for example, can use apps to help themselves monitor their diseases, as well as help physicians to create tailor-made treatment plans [117]. Some other advantages can be derived from sharing real-time data between researchers via (secure) platforms as well as storing and replacing data from one software function to another without data loss or mistakes in data entry [106,116]. Rapid data synchronization between data entry (from the user) and demand-oriented provision of the data (for the researcher or the physician) is also possible [116]. Data entry occurs almost simultaneously with its storage and access, which saves time and increases effectivity. With the support of smartphone devices, data collection is possible on a daily basis over long periods of time, and questionnaire responses can be tracked longitudinally [117]. Smartphone-based interventions, or aftercare assessment via the smartphone (in lieu of going to a hospital or seeing a physician), remove barriers and save time; they also remove administrative barriers and travel difficulties (eg, for aftercare assessment). Furthermore, data loss due to reminder bias can be prevented [116].

With sensitive (health) data, there is always a need for data protection. When using secure data storage and unique random codes for user identification, anonymity and data security can be ensured by using apps [106,117].

\section{Challenges in Using Smartphone Devices for Data Collection Over Time}

Although data collection with smartphone apps has great potential, there are also challenges and disadvantages. As is the case for traditional methods of data collection, follow-up with smartphones can be nonuniform [106]. For that reason, users' (or patients') engagement and compliance over longer periods of time is a critical issue. Optimally, for conducting studies on smartphone devices, people need to own smartphones with an available mobile internet connection. Otherwise, it is necessary to provide these devices to the participants. This might be feasible for a cross-sectional study of short duration, but for large sample sizes and over longer periods of time this is an obstacle [110]. Furthermore, participant-related preferences are to carry no more than one device $[109,121]$. Overall, a risk of loss to follow-up exists [108], as in other longitudinal data collections, which might be due to either lack of motivation or technical issues, such as poor data signal or participant discomfort using mobile phones [120]. Therefore, interactive and feedback elements and rewards may lead to greater adherence [112,113].

\section{Discussion}

\section{Overview}

Although the studies identified in this scoping review claimed significant potential for health-related data collection using smartphone devices, it is obvious that very few approaches have integrated these devices into clinical or epidemiological research activities so far. This is particularly true for the data collection in longitudinal study designs. Although apps can be simply tailored to the needs of target groups [12], only a few studies $[108,109,120,122]$ focused explicitly on specified groups. Most of the articles identified in this review dealt with a particular medical or health-related issue. However, apart from pregnancy and childhood, the study participants consisted of nonspecific target groups. For example, we were not able to identify any study particularly focusing on migrant populations. Therefore, the main result of this overview about mobile apps for data collection in epidemiological research is that further studies and, depending on the results of such studies, adequate solutions for implementing modern technologies for data collection in a priori defined target groups is urgently needed. This is also a requirement for achieving high usability. Although it is possible to design an app using free or low-cost development tools, this can be difficult when app designers are unfamiliar with these tools. In such cases, a pilot test with a subpopulation is highly recommended [11]. This is particularly important because a previous study [10] has indicated greater commitment and engagement in using app-based data collection tools, especially among young and middle-aged populations as compared to older populations.

General population surveys frequently do not adequately represent population subgroups. This challenge is reinforced by the fact that specific groups, such as migrants or refugees, are difficult-to-sample populations. These challenges apply to the fact that such difficult-to-sample populations can be rare, difficult to locate, difficult to enumerate, and/or difficult to interview [123]. Therefore, the implementation of mobile apps for data collection might be particularly suitable for vulnerable but also highly mobile populations, such as migrants, in general, or refugees in particular. Accurate data about health status, health determinants, use of health-care services, and risk behaviors among migrants are needed in order to monitor health and improve health services among this population subgroup [124]. As of yet, health-related data on migrants, and refugees in particular, are scarce, and data-collection approaches face several methodological limitations.

As already highlighted in a narrative review of data-collection practices for monitoring migrant health in Europe [124], there are several legal obstacles related to data protection which need to be taken into account. Due to the recently enforced European General Data Protection Regulation [125], aspects of informed consent, privacy and confidentiality, and the right to withdrawal or omit items will receive further attention in the future. These new data protection regulations need to be kept in mind when developing and implementing data-collection tools. These tools should provide additional information to already established instruments such as the census, death registers, and disease 
surveillance systems. These established instruments only partially include information on migration status, and if they do, the information is only available at a highly aggregated level [126]. Further information on the health of migrants is available based on epidemiological studies of population samples using medical diagnoses [127]. However, these analyses face the challenge that migrants may encounter barriers in accessing health services. This may lead to an underestimation of the disease burden [127].

To overcome these challenges, which lead to an underrepresentation of specific subgroups and, therefore, insufficient data for action [128], several measures have already been taken. These measures include, but are not limited to, disproportionately allocated sampling, multiplicity sampling, and the use of multiple frames. However, it has to be noted that oversampling of people with a migration background is not sufficient to avoid systematic bias in the sample due to nonparticipation. Further measures, such as personal contacting, multilingual instruments and interviewers, and extensive public relations, have to be taken into account. All of this can be done within smartphone-based apps. For the target groups of migrants in epidemiological studies, no singe simple solution exists $[123,129,130]$. However, studies indicate that constant communication and follow-up of study participants enhances the response rates in longitudinal studies and improves the quality of data [131]. For that reason, mobile apps may provide solutions for overcoming common challenges in epidemiological data collection.

\section{Limitations}

Overall, the results of this scoping review need to be interpreted with caution. We were only able to provide a broad overview of challenges and potential benefits linked with data collection using mobile apps described in the literature. The scoping review was not focused on a specific topic in epidemiological research, in order to capture all the ideas and experiences previously described in the literature. Due to the comparatively broad (but not concrete) search algorithm that included terms related to mobile apps in combination with study designs, we might have missed some studies which have applied mobile technologies in epidemiological data collection. For example, mobile phone surveys have been excluded. However, although this scoping review was conducted in only one literature database (PubMed), we anticipate that it will provide a comprehensive overview of the potential benefits and challenges that researchers may face when using mobile apps for data collection in epidemiological studies. We were not able to identify studies specifically dealing with the target group of migrants or refugees.

\section{Conclusions}

It appears that the challenges connected to data collection among migrant subgroups can be overcome by using the innovative technologies of mobile apps. These approaches allow the recruitment of study participants from diverse ethnic backgrounds when designed in a migration-sensitive, cross-language, and cross-cultural fashion. Continuing contact with study participants can be ensured during longitudinal studies. This is of particular relevance for mobile populations, such as refugees, who might not have reached their place of destination at the time of recruitment. Furthermore, due to the cost-effectiveness of app-based data collection, the challenges of small sample sizes and low response rates can be at least partially overcome. However, feasibility studies need to be conducted in the near future to test the applicability and acceptance of mobile apps for epidemiological research among various subpopulations.

\section{Acknowledgments}

We acknowledge support from the German Research Foundation (DFG) and the Open Access Publication Fund of Charité Universitätsmedizin Berlin.

\section{Conflicts of Interest}

None declared.

\section{Multimedia Appendix 1}

Supplementary appendix. [PDF File (Adobe PDF File), 96 KB-Multimedia Appendix 1]

\section{References}

1. Statista. Anzahl der Smartphone-Nutzer weltweit von 2016 bis 2019 und Prognose bis 2023. 2021. URL: https://de. statista.com/statistik/daten/studie/309656/umfrage/prognose-zur-anzahl-der-smartphone-nutzer-weltweit/ [accessed 2021-01-14]

2. Research 2 Guidance. mHealth App Developer Economics 2015: The current status and trends of the mHealth app market. 2017. URL: http://research2guidance.com/r2g/r2g-mHealth-App-Developer-Economics-2015.pdf [accessed 2021-01-14]

3. Kim JH, Kwon S, Shim SR, Sun HY, Ko YM, Chun D, et al. Validation and reliability of a smartphone application for the International Prostate Symptom Score questionnaire: a randomized repeated measures crossover study. J Med Internet Res 2014 Feb 10;16(2):e38 [FREE Full text] [doi: 10.2196/jmir.3042] [Medline: 24513507]

4. Ozdalga E, Ozdalga A, Ahuja N. The smartphone in medicine: a review of current and potential use among physicians and students. J Med Internet Res 2012 Sep 27;14(5):e128 [FREE Full text] [doi: 10.2196/jmir.1994] [Medline: 23017375] 
5. Behar J, Roebuck A, Domingos JS, Gederi E, Clifford GD. A review of current sleep screening applications for smartphones. Physiol Meas 2013 Jun 17;34(7):R29-R46. [doi: 10.1088/0967-3334/34/7/r29]

6. Pfaeffli L, Maddison R, Jiang Y, Dalleck L, Löf M. Measuring Physical Activity in a Cardiac Rehabilitation Population Using a Smartphone-Based Questionnaire. J Med Internet Res 2013 Mar 22;15(3):e61. [doi: 10.2196/jmir.2419]

7. Palmier-Claus JE, Ainsworth J, Machin M, Barrowclough C, Dunn G, Barkus E, et al. The feasibility and validity of ambulatory self-report of psychotic symptoms using a smartphone software application. BMC Psychiatry 2012 Oct 17;12:172 [FREE Full text] [doi: 10.1186/1471-244X-12-172]

8. Dufau S, Duñabeitia JA, Moret-Tatay C, McGonigal A, Peeters D, Alario F, et al. Smart phone, smart science: how the use of smartphones can revolutionize research in cognitive science. PLoS One 2011 Sep;6(9):e24974 [FREE Full text] [doi: 10.1371/journal.pone.0024974] [Medline: 21980370]

9. Abelson JS, Symer M, Peters A, Charlson M, Yeo H. Mobile health apps and recovery after surgery: What are patients willing to do? The American Journal of Surgery 2017 Oct;214(4):616-622. [doi: 10.1016/j.amjsurg.2017.06.009]

10. BinDhim NF, Shaman AM, Trevena L, Basyouni MH, Pont LG, Alhawassi TM. Depression screening via a smartphone app: cross-country user characteristics and feasibility. J Am Med Inform Assoc 2014 Oct 17;22(1):29-34. [doi: 10.1136/amiajnl-2014-002840]

11. Burnay E, Cruz-Correia R, Jacinto T, Sousa AS, Fonseca J. Challenges of a mobile application for asthma and allergic rhinitis patient enablement-interface and synchronization. Telemed J E Health 2013 Jan;19(1):13-18. [doi:

10.1089/tmj.2012.0020] [Medline: 23215639]

12. Hartin P, Nugent C, McClean S. A smartphone application to evaluate technology adoption and usage in persons with dementia. 2014 Presented at: Conf Proc IEEE Eng Med Biol Soc; 2014; Chicago p. 5389-5392. [doi: 10.1109/embc.2014.6944844]

13. Min YH, Lee JW, Shin Y, Jo M, Sohn G, Lee J, et al. Daily collection of self-reporting sleep disturbance data via a smartphone app in breast cancer patients receiving chemotherapy: a feasibility study. J Med Internet Res 2014 May;16(5):e135 [FREE Full text] [doi: 10.2196/jmir.3421] [Medline: 24860070]

14. Mulhern B, O'Gorman H, Rotherham N, Brazier J. Comparing the measurement equivalence of EQ-5D-5L across different modes of administration. Health Qual Life Outcomes 2015 Nov 26;13:191. [doi: 10.1186/s12955-015-0382-6]

15. Serrano KJ, Yu M, Riley WT, Patel V, Hughes P, Marchesini K, et al. Willingness to Exchange Health Information via Mobile Devices: Findings From a Population-Based Survey. Ann Fam Med 2016 Jan;14(1):34-40 [FREE Full text] [doi: 10.1370/afm.1888] [Medline: 26755781]

16. Wang J, Yao NA, Liu Y, Geng Z, Wang Y, Shen N, et al. Development of a Smartphone Application to Monitor Pediatric Patient-Reported Outcomes. Stud Health Technol Inform 2017;245:253-257. [Medline: 29295093]

17. Marcano Belisario JS, Doherty K, O'Donoghue J, Ramchandani P, Majeed A, Doherty G, et al. A bespoke mobile application for the longitudinal assessment of depression and mood during pregnancy: protocol of a feasibility study. BMJ Open 2017 May 29;7(5):e014469. [doi: 10.1136/bmjopen-2016-014469]

18. Abu-Ghanem S, Handzel O, Ness L, Ben-Artzi-Blima M, Fait-Ghelbendorf K, Himmelfarb M. Smartphone-based audiometric test for screening hearing loss in the elderly. Eur Arch Otorhinolaryngol 2016;273(2):333-339. [doi: 10.1007/s00405-015-3533-9] [Medline: 25655259]

19. Brooks GC, Vittinghoff E, Iyer S, Tandon D, Kuhar P, Madsen KA, et al. Accuracy and Usability of a Self-Administered 6-Minute Walk Test Smartphone Application. Circ Heart Fail 2015 Sep;8(5):905-913. [doi:

10.1161/CIRCHEARTFAILURE.115.002062]

20. Dempster NJ, Risk R, Clark R, Meddings RN. Urologists' usage and perceptions of urological apps. J Telemed Telecare 2014 Dec;20(8):450-453. [doi: 10.1177/1357633X14555622] [Medline: 25316043]

21. Sheehan B, Lee Y, Rodriguez M, Tiase V, Schnall R. A comparison of usability factors of four mobile devices for accessing healthcare information by adolescents. Appl Clin Inform 2012 Dec;3(4):356-366 [FREE Full text] [doi: 10.4338/ACI-2012-06-RA-0021] [Medline: 23227134]

22. Snipes SA, Smyth JM, Murphy D, Miranda PY, Ishino FAM. Provision Increases Reported PPE Use for Mexican Immigrant Farmworkers. Journal of Occupational and Environmental Medicine 2015;57(12):1343-1346. [doi: 10.1097/jom.0000000000000563]

23. Tawara S, Yonemochi Y, Kosaka T, Kouzaki Y, Takita T, Tsuruta T. Use of Patients' Mobile Phones to Store and Share Personal Health Information: Results of a Questionnaire Survey. Intern Med 2013;52(7):751-756. [doi: 10.2169/internalmedicine.52.9030]

24. Zhang MW, Ho CS, Fang P, Lu Y, Ho RC. Methodology of developing a smartphone application for crisis research and its clinical application. Technol Health Care 2014 Aug 01;22(4):547-559. [doi: 10.3233/thc-140819]

25. Bajaj JS, Thacker LR, Heuman DM, Fuchs M, Sterling RK, Sanyal AJ, et al. The Stroop smartphone application is a short and valid method to screen for minimal hepatic encephalopathy. Hepatology 2013 Sep;58(3):1122-1132 [FREE Full text] [doi: 10.1002/hep.26309] [Medline: 23389962]

26. Mehta S, Barker K, Bowman B, Galloway H, Oliashirazi N, Oliashirazi A. Reliability, Concurrent Validity, and Minimal Detectable Change for iPhone Goniometer App in Assessing Knee Range of Motion. J Knee Surg 2016 Nov 28;30(6):577-584. [doi: 10.1055/s-0036-1593877] 
27. Arsand E, Tatara N, ostengen G, Hartvigsen G. Mobile Phone-Based Self-Management Tools for Type 2 Diabetes: The Few Touch Application. Journal of Diabetes Science and Technology 2010 Mar 01;4(2):328-336. [doi: $10.1177 / 193229681000400213]$

28. Azevedo R, Bernardes M, Fonseca J, Lima A. Smartphone application for rheumatoid arthritis self-management: cross-sectional study revealed the usefulness, willingness to use and patients' needs. Rheumatol Int 2015;35(10):1675-1685. [doi: 10.1007/s00296-015-3270-9] [Medline: 25903352]

29. Becker S, Brandl C, Meister S, Nagel E, Miron-Shatz T, Mitchell A, et al. Demographic and health related data of users of a mobile application to support drug adherence is associated with usage duration and intensity. PLoS One 2015 Jan;10(1):e0116980 [FREE Full text] [doi: 10.1371/journal.pone.0116980] [Medline: 25629939]

30. Becker S, Kribben A, Meister S, Diamantidis CJ, Unger N, Mitchell A. User Profiles of a Smartphone Application to Support Drug Adherence — Experiences from the iNephro Project. PLoS ONE 2013 Oct 23;8(10):e78547. [doi: 10.1371/journal.pone.0078547]

31. Liu X, Wang R, Zhou D, Hong Z. Feasibility and acceptability of smartphone applications for seizure self-management in China: Questionnaire study among people with epilepsy. Epilepsy Behav 2016 Feb;55:57-61. [doi: 10.1016/j.yebeh.2015.11.024] [Medline: 26745631]

32. Reynoldson C, Stones C, Allsop M, Gardner P, Bennett MI, Closs SJ, et al. Assessing the quality and usability of smartphone apps for pain self-management. Pain Med 2014 Jun;15(6):898-909 [FREE Full text] [doi: 10.1111/pme.12327] [Medline: 24422990]

33. Shah N, Jonassaint J, De Castro L. Patients Welcome the Sickle Cell Disease Mobile Application to Record Symptoms Technology (SMART). Hemoglobin 2014 Feb 10;38(2):99-103. [doi: 10.3109/03630269.2014.880716]

34. Tregarthen JP, Lock J, Darcy AM. Development of a smartphone application for eating disorder self-monitoring. Int J Eat Disord 2015 Jul 27;48(7):972-982. [doi: 10.1002/eat.22386]

35. Zhang MW, Ho RC, Hawa R, Sockalingam S. Pilot implementation and user preferences of a Bariatric After-care application. Technol Health Care 2015 Oct 27;23(6):729-736. [doi: 10.3233/thc-151025]

36. Atkinson KM, Ducharme R, Westeinde J, Wilson SE, Deeks SL, Pascali D, et al. Vaccination attitudes and mobile readiness: A survey of expectant and new mothers. Human Vaccines \& Immunotherapeutics 2015 Feb 25;11(4):1039-1045. [doi: $10.1080 / 21645515.2015 .1009807]$

37. Conway N, Campbell I, Forbes P, Cunningham S, Wake D. mHealth applications for diabetes: User preference and implications for app development. Health Informatics J 2016;22(4):1111-1120. [doi: 10.1177/1460458215616265] [Medline: 26635324]

38. Alenazi H, Alghamdi M, Alradhi S, Househ M, Zakaria N. A Study on Saudi Diabetic Patients' Readiness to Use Mobile Health. Stud Health Technol Inform 2017;245:1210. [Medline: 29295297]

39. Swendeman D, Ramanathan N, Baetscher L, Medich M, Scheffler A, Comulada WS, et al. Smartphone Self-Monitoring to Support Self-Management Among People Living With HIV. J Acquir Immune Defic Syndr 2015 May 01;69(Suppl. 1):S80-S91. [doi: 10.1097/qai.0000000000000570]

40. Barrio P, Ortega L, López H, Gual A. Self-management and Shared Decision-Making in Alcohol Dependence via a Mobile App: a Pilot Study. Int J Behav Med 2017 Feb 24;24(5):722-727. [doi: 10.1007/s12529-017-9643-6]

41. Con D, Jackson B, Gray K, De Cruz P. eHealth for inflammatory bowel disease self-management - the patient perspective. Scand J Gastroenterol 2017 Jun 9;52(9):973-980. [doi: 10.1080/00365521.2017.1333625]

42. Crosby LE, Ware RE, Goldstein A, Walton A, Joffe NE, Vogel C, et al. Development and evaluation of iManage: A self-management app co-designed by adolescents with sickle cell disease. Pediatr Blood Cancer 2017 Jan;64(1):139-145. [doi: 10.1002/pbc.26177] [Medline: 27574031]

43. Eisenhauer CM, Hageman PA, Rowland S, Becker BJ, Barnason SA, Pullen CH. Acceptability of mHealth Technology for Self-Monitoring Eating and Activity among Rural Men. Public Health Nurs 2017 Mar;34(2):138-146. [doi: 10.1111/phn.12297] [Medline: 27757986]

44. Lee J, Song S, Ahn J, Kim Y, Lee J. Use of a Mobile Application for Self-Monitoring Dietary Intake: Feasibility Test and an Intervention Study. Nutrients 2017 Jul 13;9(7):748. [doi: 10.3390/nu9070748]

45. Simpson AJ, Honkoop PJ, Kennington E, Snoeck-Stroband J, Smith I, East J, et al. Perspectives of patients and healthcare professionals on mHealth for asthma self-management. Eur Respir J 2017 May 01;49(5):1601966. [doi: 10.1183/13993003.01966-2016]

46. Sommer J, Daus M, Smith M, Luna D. Mobile Application for Pregnant Women: What Do Mothers Say? Stud Health Technol Inform 2017;245:221-224. [Medline: 29295086]

47. Yu DX, Parmanto B, Dicianno BE, Watzlaf VJ, Seelman KD. Accessibility needs and challenges of a mHealth system for patients with dexterity impairments. Disabil Rehabi Assist Technol 2017 Jan;12(1):56-64. [doi: 10.3109/17483107.2015.1063171]

48. Jiam NT, Hoon AH, Hostetter CF, Khare MM. IIAM (important information about me): a patient portability profile app for adults, children and families with neurodevelopmental disabilities. Disabil Rehabil Assist Technol 2017

Dec;12(6):599-604. [doi: 10.1080/17483107.2016.1198435] [Medline: 27377240] 
49. Bielli E, Carminati F, La CS, Lina M, Brunelli C, Tamburini M. A Wireless Health Outcomes Monitoring System (WHOMS): development and field testing with cancer patients using mobile phones. BMC Med Inform Decis Mak 2004 Jun 15;4:7 [FREE Full text] [doi: 10.1186/1472-6947-4-7] [Medline: 15196308]

50. Dunton GF, Liao Y, Intille SS, Spruijt-Metz D, Pentz M. Investigating children's physical activity and sedentary behavior using ecological momentary assessment with mobile phones. Obesity (Silver Spring) 2011 Jun;19(6):1205-1212 [FREE Full text] [doi: 10.1038/oby.2010.302] [Medline: 21164502]

51. Eagle N, Pentland A, Lazer D. Inferring friendship network structure by using mobile phone data. Proceedings of the National Academy of Sciences 2009 Aug 17;106(36):15274-15278. [doi: 10.1073/pnas.0900282106]

52. Jovanov E, Frith K, Anderson F, Milosevic M, Shrove M. Real-time monitoring of occupational stress of nurses. 2011 Presented at: Conf Proc IEEE Eng Med Biol Soc; 2011; Boston p. 3640-3643. [doi: 10.1109/iembs.2011.6090612]

53. Dewulf B, Neutens T, Lefebvre W, Seynaeve G, Vanpoucke C, Beckx C, et al. Dynamic assessment of exposure to air pollution using mobile phone data. Int J Health Geogr 2016 Apr 21;15(1):14. [doi: 10.1186/s12942-016-0042-z]

54. Saeb S, Zhang M, Karr CJ, Schueller SM, Corden ME, Kording KP, et al. Mobile Phone Sensor Correlates of Depressive Symptom Severity in Daily-Life Behavior: An Exploratory Study. J Med Internet Res 2015 Jul 15;17(7):e175 [FREE Full text] [doi: 10.2196/jmir.4273] [Medline: 26180009]

55. McLean A, Osgood N, Newstead-Angel J, Stanley K, Knowles D, van der Kamp W, et al. Building Research Capacity: Results of a Feasibility Study Using a Novel mHealth Epidemiological Data Collection System Within a Gestational Diabetes Population. Stud Health Technol Inform 2017;234:228-232. [Medline: 28186046]

56. Katib A, Rao D, Rao P, Williams K, Grant J. A prototype of a novel cell phone application for tracking the vaccination coverage of children in rural communities. Comput Methods Programs Biomed 2015 Nov;122(2):215-228. [doi: 10.1016/j.cmpb.2015.08.008]

57. Haskew J, Kenyi V, William J, Alum R, Puri A, Mostafa Y, et al. Use of Mobile Information Technology during Planning, Implementation and Evaluation of a Polio Campaign in South Sudan. PLoS ONE 2015 Aug 7;10(8):e0135362. [doi: 10.1371/journal.pone.0135362]

58. Rajput ZA, Mbugua S, Amadi D, Chepngeno V, Saleem JJ, Anokwa Y, et al. Evaluation of an Android-based mHealth system for population surveillance in developing countries. J Am Med Inform Assoc 2012 Jul 01;19(4):655-659. [doi: 10.1136/amiajnl-2011-000476]

59. Rotheram-Borus M, Richter L, Van RH, van HA, Tomlinson M, Stein A, et al. Project Masihambisane: a cluster randomised controlled trial with peer mentors to improve outcomes for pregnant mothers living with HIV. Trials 2011 Jan 04;12:2 [FREE Full text] [doi: 10.1186/1745-6215-12-2] [Medline: 21205302]

60. Setswe G, Muyanga S, Witthun J, Nyasulu P. Public awareness and knowledge of the National Health Insurance in South Africa. Pan Afr Med J 2015;22(19):1-10. [doi: 10.11604/pamj.2015.22.19.6131]

61. Tomlinson M, Solomon W, Singh Y, Doherty T, Chopra M, Ijumba P, et al. The use of mobile phones as a data collection tool: a report from a household survey in South Africa. BMC Med Inform Decis Mak 2009 Dec 23;9:51 [FREE Full text] [doi: 10.1186/1472-6947-9-51] [Medline: 20030813]

62. Vélez O, Okyere PB, Kanter AS, Bakken S. A usability study of a mobile health application for rural Ghanaian midwives. J Midwifery Womens Health 2014 Jan;59(2):184-191 [FREE Full text] [doi: 10.1111/jmwh.12071] [Medline: 24400748]

63. Zhang S, Wu Q, van Velthoven MH, Chen L, Car J, Rudan I, et al. Smartphone Versus Pen-and-Paper Data Collection of Infant Feeding Practices in Rural China. J Med Internet Res 2012 Sep 18;14(5):e119. [doi: 10.2196/jmir.2183]

64. Knoble SJ, Bhusal MR. Electronic diagnostic algorithms to assist mid-level health care workers in Nepal: A mixed-method exploratory study. Int J Med Inform 2015 May;84(5):334-340. [doi: 10.1016/j.ijmedinf.2015.01.011]

65. Andrew BY, Stack CM, Yang JP, Dodds JA. mStroke: "Mobile Stroke"-Improving Acute Stroke Care with Smartphone Technology. J Stroke Cerebrovasc Dis 2017 Jul;26(7):1449-1456. [doi: 10.1016/j.jstrokecerebrovasdis.2017.03.016]

66. Bakibinga P, Kamande E, Omuya M, Ziraba AK, Kyobutungi C. The role of a decision-support smartphone application in enhancing community health volunteers' effectiveness to improve maternal and newborn outcomes in Nairobi, Kenya: quasi-experimental research protocol. BMJ Open 2017 Jul 20;7(7):e014896 [FREE Full text] [doi: 10.1136/bmjopen-2016-014896] [Medline: 28729309]

67. Coppock D, Zambo D, Moyo D, Tanthuma G, Chapman J, Re VL, et al. Development and Usability of a Smartphone Application for Tracking Antiretroviral Medication Refill Data for Human Immunodeficiency Virus. Methods Inf Med 2018 Jan 24;56(5):351-359. [doi: 10.3414/me17-01-0045]

68. Kenny A, Gordon N, Griffiths T, Kraemer JD, Siedner MJ. Validation Relaxation: A Quality Assurance Strategy for Electronic Data Collection. J Med Internet Res 2017 Aug 18;19(8):e297. [doi: 10.2196/jmir.7813]

69. Mishori R, Anastario M, Naimer K, Varanasi S, Ferdowsian H, Abel D, et al. mJustice: Preliminary Development of a Mobile App for Medical-Forensic Documentation of Sexual Violence in Low-Resource Environments and Conflict Zones. Glob Health Sci Pract 2017 Mar 28;5(1):138-151. [doi: 10.9745/ghsp-d-16-00233]

70. Modi D, Desai S, Dave K, Shah S, Desai G, Dholakia N, et al. Cluster randomized trial of a mHealth intervention "ImTeCHO" to improve delivery of proven maternal, neonatal, and child care interventions through community-based Accredited Social Health Activists (ASHAs) by enhancing their motivation and strengthening supervision in tribal areas of Gujarat, India: study protocol for a randomized controlled trial. Trials 2017 Jun 9;18(1):270. [doi: 10.1186/s13063-017-1998-0] 
71. Motulsky A, Wong J, Cordeau J, Pomalaza J, Barkun J, Tamblyn R. Using mobile devices for inpatient rounding and handoffs: an innovative application developed and rapidly adopted by clinicians in a pediatric hospital. J Am Med Inform Assoc 2016 Aug 22;24(e1):e69-e78. [doi: 10.1093/jamia/ocw107]

72. Vedachalam S, MacDonald LH, Shiferaw S, Seme A, Schwab KJ. Underreporting of high-risk water and sanitation practices undermines progress on global targets. PLoS ONE 2017 May 10;12(5):e0176272. [doi: 10.1371/journal.pone.0176272]

73. Zhou L, Watzlaf V, Abernathy P, Abdelhak M. A Health Information System for Scalable and Comprehensive Assessment of Well-Being: A Multidisciplinary Team Solution. Perspect Health Inf Manag 2017 Jul 01;14(Summer):1d [FREE Full text] [Medline: 28855857]

74. Runyan JD, Steenbergh TA, Bainbridge C, Daugherty DA, Oke L, Fry BN. A smartphone ecological momentary assessment/intervention. PLoS One 2013 Aug;8(8):e71325 [FREE Full text] [doi: 10.1371/journal.pone.0071325] [Medline: $\underline{23977016}$ ]

75. Spook JE, Paulussen T, Kok G, Van EP. Monitoring dietary intake and physical activity electronically: feasibility, usability, and ecological validity of a mobile-based Ecological Momentary Assessment tool. J Med Internet Res 2013;15(9):e214 [FREE Full text] [doi: 10.2196/jmir.2617] [Medline: 24067298]

76. Webb JR, Webb BF, Schroeder MC, North CS. Association of aphthous ulcers with self-reported symptoms of depression in a sample of smartphone users. Ann Clin Psychiatry 2013 Nov;25(4):266-270. [Medline: 24199216]

77. Seto E, Hua J, Wu L, Shia V, Eom S, Wang M, et al. Models of Individual Dietary Behavior Based on Smartphone Data: The Influence of Routine, Physical Activity, Emotion, and Food Environment. PLoS One 2016;11(4):e0153085 [FREE Full text] [doi: 10.1371/journal.pone.0153085] [Medline: 27049852]

78. Reid SC, Kauer SD, Dudgeon P, Sanci LA, Shrier LA, Patton GC. A mobile phone program to track young people's experiences of mood, stress and coping. Development and testing of the mobiletype program. Soc Psychiatry Psychiatr Epidemiol 2009 Jun;44(6):501-507. [doi: 10.1007/s00127-008-0455-5] [Medline: 19011723]

79. Stinson JN, Jibb LA, Nguyen C, Nathan PC, Maloney AM, Dupuis LL, et al. Construct validity and reliability of a real-time multidimensional smartphone app to assess pain in children and adolescents with cancer. Pain 2015 Dec;156(12):2607-2615. [doi: 10.1097/j.pain.0000000000000385] [Medline: 26580680]

80. Brannon EE, Cushing CC, Crick CJ, Mitchell TB. The promise of wearable sensors and ecological momentary assessment measures for dynamical systems modeling in adolescents: a feasibility and acceptability study. Transl Behav Med 2016 Dec;6(4):558-565 [FREE Full text] [doi: 10.1007/s13142-016-0442-4] [Medline: 27678501]

81. Warren-Stomberg M, Jacobsson J, Brattwall M, Jildenstål P. At-home monitoring after surgery/anaesthesia - a challenge. J Eval Clin Pract 2016 May 01;22(6):886-890. [doi: 10.1111/jep.12551]

82. Alqahtani AS, Rashid H, Basyouni MH, Alhawassi TM, BinDhim NF. Public response to MERS-CoV in the Middle East: iPhone survey in six countries. J Infect Public Health 2017 Sep;10(5):534-540. [doi: 10.1016/j.jiph.2016.11.015]

83. Chen Y, Wong J, Ayob A, Othman N, Poh B. Can Malaysian Young Adults Report Dietary Intake Using a Food Diary Mobile Application? A Pilot Study on Acceptability and Compliance. Nutrients 2017 Jan 13;9(1):62. [doi: 10.3390/nu9010062]

84. Farnham A, Furrer R, Blanke U, Stone E, Hatz C, Puhan M. The quantified self during travel: mapping health in a prospective cohort of travellers. J Travel Med 2017 Sep 01;24(5):tax050. [doi: 10.1093/jtm/tax050] [Medline: 28931147]

85. Fernández-Castro J, Martínez-Zaragoza F, Rovira T, Edo S, Solanes-Puchol ?, Martín-del-Río B, et al. How does emotional exhaustion influence work stress? Relationships between stressor appraisals, hedonic tone, and fatigue in nurses' daily tasks: A longitudinal cohort study. Int J Nurs Stud 2017 Oct;75:43-50. [doi: 10.1016/j.ijnurstu.2017.07.002]

86. Gomes MS, Bonan PRF, Ferreira VYN, de Lucena Pereira L, Correia RJC, da Silva Teixeira HB, et al. Development of a mobile application for oral cancer screening. Technol Health Care 2017 Mar 22;25(2):187-195. [doi: 10.3233/thc-161259]

87. Hennig T, Krkovic K, Lincoln TM. What predicts inattention in adolescents? An experience-sampling study comparing chronotype, subjective, and objective sleep parameters. Sleep Med 2017 Oct;38:58-63. [doi: 10.1016/j.sleep.2017.07.009]

88. Kaplan-Neeman R, Muchnik C, Amir N. Listening to music with personal listening devices: monitoring the noise dose using a smartphone application. Int J Audiol 2017 Mar 10;56(6):400-407. [doi: 10.1080/14992027.2017.1297541]

89. Liddle J, Wishink A, Springfield L, Gustafsson L, Ireland D, Silburn P. Can smartphones measure momentary quality of life and participation? A proof of concept using experience sampling surveys with university students. Aust Occup Ther J 2017 Apr 06;64(4):294-304. [doi: 10.1111/1440-1630.12360]

90. Mindell JA, Leichman ES, Walters RM. Sleep location and parent-perceived sleep outcomes in older infants. Sleep Med 2017 Nov;39:1-7. [doi: 10.1016/j.sleep.2017.08.003]

91. Moore RC, Kaufmann CN, Rooney AS, Moore DJ, Eyler LT, Granholm E, et al. Feasibility and Acceptability of Ecological Momentary Assessment of Daily Functioning Among Older Adults with HIV. Am J Geriatr Psychiatry 2017 Aug;25(8):829-840. [doi: 10.1016/j.jagp.2016.11.019]

92. Moran EK, Culbreth AJ, Barch DM. Ecological momentary assessment of negative symptoms in schizophrenia: Relationships to effort-based decision making and reinforcement learning. J Abnorm Psychol 2017 Jan;126(1):96-105. [doi: $\underline{10.1037 / \mathrm{abn} 0000240]}$ 
93. Roberts ME, Lu B, Browning CR, Ferketich AK. Tracking Young Adults' Attitudes Toward Tobacco Marketing Using Ecological Momentary Assessment (EMA). Subst Use Misuse 2017 Jun 12;52(9):1208-1213. [doi: $10.1080 / 10826084.2017 .1302958]$

94. Roy R, Rangan A, Hebden L, Yu Louie JC, Tang LM, Kay J, et al. Dietary contribution of foods and beverages sold within a university campus and its effect on diet quality of young adults. Nutrition 2017 Feb;34:118-123. [doi: 10.1016/j.nut.2016.09.013]

95. Sperry SH, Kwapil TR. What can daily life assessment tell us about the bipolar spectrum? Psychiatry Res 2017 Jun;252:51-56. [doi: 10.1016/j.psychres.2017.02.045]

96. Timmer BHB, Hickson L, Launer S. Ecological Momentary Assessment: Feasibility, Construct Validity, and Future Applications. Am J Audiol 2017 Oct 12;26(3S):436-442. [doi: 10.1044/2017_aja-16-0126]

97. van Wel L, Huss A, Bachmann P, Zahner M, Kromhout H, Fröhlich J, et al. Context-sensitive ecological momentary assessments; integrating real-time exposure measurements, data-analytics and health assessment using a smartphone application. Environ Int 2017 Jun;103:8-12. [doi: 10.1016/j.envint.2017.03.016]

98. Wang J, Wang Q, Wimalaratne I, Menkes DB, Wang X. Chinese non-psychiatric hospital doctors' attitudes toward management of psychological/psychiatric problems. BMC Health Serv Res 2017 Aug 22;17:576. [doi: 10.1186/s12913-017-2521-8]

99. Worthen-Chaudhari L, McGonigal J, Logan K, Bockbrader MA, Yeates KO, Mysiw WJ. Reducing concussion symptoms among teenage youth: Evaluation of a mobile health app. Brain Inj 2017 Jun 30;31(10):1279-1286. [doi: $10.1080 / 02699052.2017 .1332388]$

100. Pelletier J, Rowe M, François N, Bordeleau J, Lupien S. No personalization without participation: on the active contribution of psychiatric patients to the development of a mobile application for mental health. BMC Med Inform Decis Mak 2013 Jul 27;13:78 [FREE Full text] [doi: 10.1186/1472-6947-13-78] [Medline: 23890085]

101. Bousquet J, Bewick M, Arnavielhe S, Mathieu-Dupas E, Murray R, Bedbrook A, et al. Work productivity in rhinitis using cell phones: The MASK pilot study. Allergy 2017 Jun 09;72(10):1475-1484. [doi: 10.1111/all.13177]

102. Marcano Belisario JS, Jamsek J, Huckvale K, O'Donoghue J, Morrison CP, Car J. Comparison of self-administered survey questionnaire responses collected using mobile apps versus other methods. Cochrane Database Syst Rev 2015 Jul 27;7:MR000042. [doi: 10.1002/14651858.MR000042.pub2] [Medline: 26212714]

103. Pombo N, Garcia N, Bousson K, Spinsante S, Chorbev I. Pain Assessment-Can it be Done with a Computerised System? A Systematic Review and Meta-Analysis. Int J Environ Res Pub Health 2016 Apr 13;13(4):415. [doi: 10.3390/ijerph13040415]

104. Udtha M, Nomie K, Yu E, Sanner J. Novel and Emerging Strategies for Longitudinal Data Collection. J Nurs Scholarsh 2014 Dec 09;47(2):152-160. [doi: 10.1111/jnu.12116]

105. Gibson DG, Pereira A, Farrenkopf BA, Labrique AB, Pariyo GW, Hyder AA. Mobile Phone Surveys for Collecting Population-Level Estimates in Low- and Middle-Income Countries: A Literature Review. J Med Internet Res 2017 May 05;19(5):e139. [doi: 10.2196/jmir.7428]

106. Bot BM, Suver C, Neto EC, Kellen M, Klein A, Bare C, et al. The mPower study, Parkinson disease mobile data collected using ResearchKit. Sci Data 2016 Mar;3:160011 [FREE Full text] [doi: 10.1038/sdata.2016.11] [Medline: 26938265]

107. Chan YY, Wang P, Rogers L, Tignor N, Zweig M, Hershman SG, et al. The Asthma Mobile Health Study, a large-scale clinical observational study using ResearchKit. Nat Biotechnol 2017 Apr;35(4):354-362 [FREE Full text] [doi: 10.1038/nbt.3826] [Medline: 28288104]

108. Demirci JR, Bogen DL. An Ecological Momentary Assessment of Primiparous Women's Breastfeeding Behavior and Problems From Birth to 8 Weeks. J Hum Lact 2017 Mar 23;33(2):285-295. [doi: 10.1177/0890334417695206]

109. Faherty LJ, Hantsoo L, Appleby D, Sammel MD, Bennett IM, Wiebe DJ. Movement patterns in women at risk for perinatal depression: use of a mood-monitoring mobile application in pregnancy. J Am Med Inform Assoc 2017 Jul 01;24(4):746-753. [doi: 10.1093/jamia/ocx005] [Medline: 28339686]

110. Horsch CH, Lancee J, Griffioen-Both F, Spruit S, Fitrianie S, Neerincx MA, et al. Mobile Phone-Delivered Cognitive Behavioral Therapy for Insomnia: A Randomized Waitlist Controlled Trial. J Med Internet Res 2017 Apr 11;19(4):e70. [doi: 10.2196/jmir.6524]

111. Isetta V, Torres M, González K, Ruiz C, Dalmases M, Embid C, et al. A New mHealth application to support treatment of sleep apnoea patients. J Telemed Telecare 2017 Jan;23(1):14-18. [doi: 10.1177/1357633X15621848] [Medline: 26672606]

112. Jamison RN, Jurcik DC, Edwards RR, Huang C, Ross EL. A Pilot Comparison of a Smartphone App With or Without 2-Way Messaging Among Chronic Pain Patients: Who Benefits From a Pain App? Clin J Pain 2017 Aug;33(8):676-686 [FREE Full text] [doi: 10.1097/AJP.0000000000000455] [Medline: 27898460]

113. Noë B, Turner LD, Linden DEJ, Allen SM, Maio GR, Whitaker RM. Timing rather than user traits mediates mood sampling on smartphones. BMC Res Notes 2017 Sep 16;10:481. [doi: 10.1186/s13104-017-2808-1]

114. Silva de Lima AL, Hahn T, Evers LJW, de Vries NM, Cohen E, Afek M, et al. Feasibility of large-scale deployment of multiple wearable sensors in Parkinson's disease. PLoS ONE 2017 Dec 20;12(12):e0189161. [doi:

10.1371/journal.pone.0189161] 
115. Sundberg K, Wengström Y, Blomberg K, Hälleberg-Nyman M, Frank C, Langius-Eklöf A. Early detection and management of symptoms using an interactive smartphone application (Interaktor) during radiotherapy for prostate cancer. Support Care Cancer 2017 Feb 24;25(7):2195-2204. [doi: 10.1007/s00520-017-3625-8] [Medline: 28236145]

116. Cooray C, Matusevicius M, Wahlgren N, Ahmed N. Mobile Phone-Based Questionnaire for Assessing 3 Months Modified Rankin Score After Acute Stroke. Circ Cardiovasc Qual Outcomes 2015 Oct 29;8(6 Suppl. 3):S125-S130. [doi: 10.1161/circoutcomes.115.002055]

117. Pavliscsak H, Little JR, Poropatich RK, McVeigh FL, Tong J, Tillman JS, et al. Assessment of patient engagement with a mobile application among service members in transition. J Am Med Inform Assoc 2015 Sep 11;23(1):110-118. [doi: 10.1093/jamia/ocv121]

118. Symer MM, Abelson JS, Milsom J, McClure B, Yeo HL. A Mobile Health Application to Track Patients After Gastrointestinal Surgery: Results from a Pilot Study. J Gastrointest Surg 2017 Sep;21(9):1500-1505. [doi: 10.1007/s11605-017-3482-2] [Medline: 28685388]

119. Labhart F, Anderson KG, Kuntsche E. The Spirit Is Willing, But the Flesh is Weak: Why Young People Drink More Than Intended on Weekend Nights-An Event-Level Study. Alcohol Clin Exp Res 2017 Oct 02;41(11):1961-1969. [doi: 10.1111/acer.13490]

120. Olson D, Lamb M, Lopez MR, Colborn K, Paniagua-Avila A, Zacarias A, et al. Performance of a Mobile Phone App-Based Participatory Syndromic Surveillance System for Acute Febrile Illness and Acute Gastroenteritis in Rural Guatemala. J

Med Internet Res 2017 Nov 09;19(11):e368. [doi: 10.2196/jmir.8041]

121. Burke LE, Shiffman S, Music E, Styn MA, Kriska A, Smailagic A, et al. Ecological Momentary Assessment in Behavioral Research: Addressing Technological and Human Participant Challenges. J Med Internet Res 2017 Dec 15;19(3):e77 [FREE Full text] [doi: 10.2196/jmir.7138] [Medline: 28298264]

122. Peleg M, Shahar Y, Quaglini S, Broens T, Budasu R, Fung N, et al. Assessment of a personalized and distributed patient guidance system. Int J Med Inform 2017 May;101:108-130. [doi: 10.1016/j.ijmedinf.2017.02.010] [Medline: 28347441]

123. Lepkowski J. Sampling the difficult-to-sample. J Nutr 1991;121(3):416-423. [doi: 10.1093/jn/121.3.416]

124. Rechel B, Mladovsky P, Devillé W. Monitoring migrant health in Europe: A narrative review of data collection practices. Health Policy 2012 Apr;105(1):10-16. [doi: 10.1016/j.healthpol.2012.01.003]

125. General Data Protection Regulation.: intersoft consulting; 2018. URL: https://gdpr-info.eu/

126. WHO. Health of migrants: The way forward, report of a global consultation, Madrid, Spain, 3 - 5 March. Geneva: World Health Organization; 2010.

127. Ingleby D. European research on migration and health: Background paper for the AMAC project. Geneva: World Health Organization; 2009.

128. Zeeb H, Razum O. Epidemiologische Studien in der Migrationsforschung. Bundesgesundheitsbl 2006 Aug 30;49(9):845-852. [doi: $10.1007 / \mathrm{s} 00103-006-0017-5]$

129. Reiss K, Makarova N, Spallek J, Zeeb H, Razum O. Identifizierung und Rekrutierung von Menschen mit Migrationshintergrund für epidemiologische Studien in Deutschland. Gesundheitswesen 2012 Aug 29;75(6):e49-e58. [doi: $10.1055 / \mathrm{s}-0032-1321768]$

130. Reiss K, Dragano N, Ellert U, Fricke J, Greiser KH, Keil T, et al. Comparing sampling strategies to recruit migrants for an epidemiological study. Results from a German feasibility study. Eur J Public Health 2014 May 27;24(5):721-726. [doi: 10.1093/eurpub/cku046]

131. Garduño-Diaz SD, Husain W, Ashkanani F, Khokhar S. Meeting challenges related to the dietary assessment of ethnic minority populations. J Hum Nutr Diet 2013 Aug 24;27(4):358-366. [doi: 10.1111/jhn.12153]

Edited by R Kukafka; submitted 04.01.20; peer-reviewed by A Nar, T Miron-Shatz; comments to author 09.09.20; revised version received 06.11.20; accepted 17.12.20; published 22.01.21

Please cite as:

Fischer F, Kleen $S$

Possibilities, Problems, and Perspectives of Data Collection by Mobile Apps in Longitudinal Epidemiological Studies: Scoping Review

J Med Internet Res 2021;23(1):e17691

URL: http://www.jmir.org/2021/1/e17691/

doi: $\underline{10.2196 / 17691}$

PMID: 33480850

CFlorian Fischer, Sina Kleen. Originally published in the Journal of Medical Internet Research (http://www.jmir.org), 22.01.2021. This is an open-access article distributed under the terms of the Creative Commons Attribution License (https://creativecommons.org/licenses/by/4.0/), which permits unrestricted use, distribution, and reproduction in any medium, provided the original work, first published in the Journal of Medical Internet Research, is properly cited. The complete bibliographic 
information, a link to the original publication on http://www.jmir.org/, as well as this copyright and license information must be included. 